Original Research Paper

\title{
Optimalisasi Pemanfaatan Lahan Pekarangan Sebagai Penyangga Ketahanan Pangan Keluarga
}

\author{
Ni Wayan Sri Suliartini ${ }^{*}$, Syavira Marwa ${ }^{2}$, Ni Putu Karina Aprilia ${ }^{3}$, M. Oktarachman $\mathbf{R}^{4}$, Ahmad Natsir \\ Ariffikri $^{5}$, Dhafin Fadhlul Aidin ${ }^{5}$, I Nyoman Sri Anggreni Laraswaty ${ }^{6}$, Muh Alfian Sangajii \\ ${ }^{1}$ Program Studi Agroekoteknologi, Universitas Mataram, Mataram, Indonesia \\ ${ }^{2}$ Program Studi Farmasi, Universitas Mataram, Mataram, Indonesia \\ ${ }^{3}$ Program Studi Agribisnis, Universitas Mataram, Mataram, Indonesia \\ ${ }^{4}$ Program Studi Akuntansi, Universitas Mataram, Mataram, Indonesia \\ ${ }^{5}$ Program Studi Hubungan Internasional, Universitas Mataram, Mataram, Indonesia \\ ${ }^{6}$ Program Studi Ilmu Hukum, Universitas Mataram, Mataram, Indonesia
}

DOI: https://doi.org/10.29303/jpmpi.v4i2.695

Sitasi: Suliartini, N. W. S., Marwa, S., Aprilia, N. P. K., Oktarachman, M., Ariffikri, A. N., Aidin, D. F., Laraswaty, I. N. S. A., \& Sangaji, M. A. (2021). Optimalisasi Pemanfaatan Lahan Pekarangan Sebagai Penyangga Ketahanan Pangan Keluarga. Jurnal Pengabdian Magister Pendidikan IPA, 4(2)

Article history

Received: 03 Februari 2021

Revised: 08 Maret 2021

Accepted: 10 April 2021

*Corresponding Author: Ni Wayan Sri Suliartini, Program Studi Agroekoteknologi, Universitas Mataram, Mataram, Indonesia;

Email:

sri.suliartini@gmail.com

\begin{abstract}
Ketahanan pangan merupakan salah satu masalah nasional yang harus ditangani bersama. Masalah ini tidak hanya ditangani oleh pemerintah, namun harus didukung aktif oleh masyarakat. Lingkungan Kelurahan Punia mempunyai tingkat kepadatan penduduk cukup tinggi dan lahan pekarangan yang sebagian besar sempit. Program Rumah Pangan Lestari (RPL) berguna dalam pengoptimalan lahan pekarangan untuk menyangga ketersedian pangan keluarga. Penulisan artikel ini disajikan secara deskriptif untuk memperoleh gambaran mengenai berbagai metode budidaya tanaman yang bermanfaat bagi masyarakat Kelurahan Punia. Berbagai program kerja yang dilakukan bertujuan untuk membuat kawasan percontohan bagi masyarakat di Kelurahan Punia agar mampu memanfaatkan lahan pekarang secara optimal untuk menjaga ketahanan pangan keluarga. Kawasan percontohan RPL bertempat di Jalan Airlangga Gang Arpom 4. Metode yang digunakan yaitu pendekatan sosial, kaji terap partisipatif, praktik demonstrasi plot. Sosialisasi RPL juga dilakukan melalui media sosial yaitu Instagram yang dilakukan mulai tanggal 11 Januari 2021 sampai dengan 24 Februari 2021. Berdasarkan hasil observasi dan kegiatan selama penerapan RPL menunjukkan masyarakat Kelurahan Punia antusias dengan program-program yang diterapkan dalam RPL. Kesimpulan yang dapat diambil dari kegiatan ini adalah program RPL berjalan dengan baik dan dapat menjadi solusi pemanfaatan lahan pekarangan untuk menyangga ketahanan pangan keluarga.
\end{abstract}

Keywords: Kelurahan Punia; Pekarangan; Rumah Pangan Lestari

\section{Pendahuluan}

Indonesia menempati urutan keempat negara dengan jumlah penduduk terbesar di dunia, setelah Republik Rakyat Tiongkok, India, dan Amerika Serikat. Pada tahun 2019, jumlah penduduk diproyeksikan mencapai sekitar 267 juta jiwa (Satiti, 2019). Laju pertumbuhan penduduk yang tinggi di Indonesia sejalan dengan meningkatnya kebutuhan pangan, karena besarnya jumlah penduduk berkaitan langsung dengan penyediaan pangan. Peningkatan jumlah penduduk juga meningkatkan persaingan antara penyediaan kebutuhan lahan untuk produksi pangan dan untuk kebutuhan lainnya (Khairati, 2016).

Kebutuhan lahan non pertanian terus mengalami peningkatan di perkotaan. Hal ini 
mengakibatkan luas lahan pertanian semakin sedikit yang akan mempengaruhi pembangunan sistem pangan masyarakat keberlanjutan dari suatu kawasan perkotaan. Minimnya lahan pertanian di perkotaan mendorong pemerintah maupun masyarakat untuk mulai mencoba memenuhi kebutuhan pangan keluarga secara mandiri serta menciptakan lingkungan yang sehat, berkualitas, dan berkelanjutan (Suryani, 2020).

Rumah Pangan Lestari merupakan prinsip pemanfaatan pekarangan yang ramah lingkungan dan dirancang untuk memenuhi kebutuhan pangan keluarga, melestarikan tanaman pangan serta meningkatkan kesejahteraan masyarakat. Masyarakat dapat memanfaatkan lahan pekarangan yang luas maupun sempit untuk menanam berbagai tanaman yang berguna untuk memenuhi kebutuhan pangan (Ashari, 2012). Menurut Sholehah (2016) Kawasan Rumah Pangan Lestari (KRPL) bertujuan mengoptimalkan lahan pekarangan rumah untuk meningkatkan ketahanan pangan dan gizi keluarga. Pemanfaatan lahan pekarangan pada pusat kawasan yang minim sarana pertanian, tidak hanya pada dimensi kegiatan pertanian hortikultur saja, namun juga kegiatan peternakan, budidaya tanaman pangan, tanaman obat dan daur ulang limbah (Suryani, 2020).

Tema Rumah Pangan Lestari dalam kegiatan KKN Era New Normal dengan judul "Optimalisasi Pemanfaatan Lahan Pekarangan sebagai Penyangga Ketahanan Pangan Keluarga" dilaksanakan di Kelurahan Punia Kota Mataram. Tujuan kegiatan ini adalah menjadi kawasan percontohan bagi masyarakat di Kelurahan Punia agar memiliki pengetahuan dan keterampilan dalam optimalisasi lahan pekarangan, melalui penanaman tanaman pangan menggunakan metode hidroponik, aquaponik, bedengan dan vertikultur, pengadaan kebun bibit serta mengolah sampah rumah tangga menjadi pupuk kompos. Kegiatan ini diharapkan menjadi solusi bagi masyarakat dalam memanfaatkan lahan pekarangan yang belum optimal untuk penyediakan pangan keluarga.

\section{Metode}

Observasi awal di Kelurahan Punia menunjukkan masih rendahnya tingkat penerapan optimalisasi lahan pekarangan di kawasan padat penduduk. Masyarakat Kelurahan Punia masih banyak yang belum memanfaatkan pekarangan rumah untuk mendukung pemenuhan kebutuhan pangan keluarga terutama sayuran. Hal ini disebabkan minimnya pengetahuan masyarakat tentang berbagai metode budidaya tanaman di pekarangan sempit maupun luas. Perlu ada kawasan percontohan yang mampu meningkatkan pemahaman dan pengetahuan masyarakat tentang budidaya tanaman dengan berbagai metode tanam, disertai demonstrasi plot yang dapat menunjukkan pada masyarakat tentang manfaat optimalisasi lahan pekarangan rumah untuk mendukung pemenuhan kebutuhan pangan secara mandiri.

Kegiatan Kuliah Kerja Nyata (KKN) atau pengabdian ini dilakukan oleh mahasiswa KKN Tematik Era New Normal tahun 2020/2021 Universitas Mataram di lingkungan Kelurahan Punia, Kota Mataram selama 45 hari terhitung mulai tanggal 11 Januari 2021 sampai dengan 24 Februari 2021. Metode yang digunakan adalah metode pendekatan sosial yang menempatkan masyarakat sebagai subyek kegiatan dan metode kaji terap partisipatif (Participatori Action Research) serta praktik demonstrasi plot (demplot). Metode terap kaji partisipan dilakukan pada anakanak Lingkungan Karang Kateng Kelurahan Punia. Sosialisasi juga dilakukan melalui media sosial yaitu instagram.

Terdapat 6 program kerja utama yaitu kebun bibit, pembuatan pupuk kompos, budidaya tanaman dengan metode bedengan, hidroponik, aquaponik, dan vertikultur. Berbagai program kerja bertujuan untuk menjadi role model bagi masyarakat di Kelurahan Punia agar mampu memanfaatkan lahan pekarangan secara optimal untuk mendukung ketahanan pangan. Adapun pelaksanaan masing-masing program kerja sebagai berikut:

\section{Identifikasi lokasi}

Identifikasi dilakukan dengan melakukan survei di daerah Kelurahan Punia untuk memperoleh lahan yang tepat sebagai tempat untuk menjalankan program RPL.

Pelaksanaan program

a. Pembuatan Denah

Lahan dibagi untuk penanaman dengan metode bedengan, vertikultur, hidroponik, dan aquaponik, lahan kebun bibit, dan lahan pembuatan pupuk organik. 
b. Pengadaan alat dan bahan

Alat-alat yang diperlukan yaitu tray semai, cepang, cangkul, tali, paku, botol bekas, kawat, ember, keranjang, alat semprot, meteran, gelas plastik, polibag, rockwool, stik es krim, pisau, pot kecil, sprayer, lilin, TDS (Total Dissolve Solid), talenan, kabel tis, kayu, box styrofoam, gunting, gerobak artco, sendok, karung, dan kain flanel. Bahan yang diperlukan yaitu media tanam (campuran tanah, sekam, dan pupuk kandang/kompos 1:1:1), POC (Pupuk Organik Cair), benih sawi, bayam merah, bayam hijau, pakcoy, selada, dan kangkung, gula, air, air beras, pisang matang, tisu, arang kayu, pupuk daun, urea, sampah dapur, bibit lele, pakan lele dan nutrisi $A B$ Mix.

c. Pengolahan Lahan atau Persiapan Media Tanam

Pengolahan lahan untuk metode bedengan dilakukan dengan mencangkul lahan agar tanah menjadi gembur. Kemudian tanah dicampur dengan pupuk kandang/kompos dan sekam. Metode vertikultur disusun secara vertikal menggunakan botol plastik bekas. Metode hidroponik menggunakan media tanam yang terbuat dari kain flannel dan air nutrisi sebagai sumber unsur hara. Wadah media hidroponik menggunakan ember, keranjang dan box styrofoam serta gelas plastik bekas. Metode aquaponik dilakukan dengan menggunakan ember dan pot kecil berisi media arang yang diikat di bibir ember, kemudian ember diisi air dan tanah lumpur.

\section{d. Pembuatan Bedengan}

Pembuatan bedengan dilakukan dengan mencangkul lahan serta menghaluskan tanah, setelah dibuat bedengan. Petakan bedengan bergantung pada luas lahan yang ada. Bila terdapat lahan yang luas, sebaiknya dibuat bedengan memanjang. Pada kegiatan ini bedengan dibuat sebanyak 4 buah, dimana 3 bedengan masingmasing berjarak $50 \mathrm{~cm}$ dengan bedengan lainnya, sedangkan 1 bedengan lain berjarak $\pm 200 \mathrm{~cm}$ dari 3 bedengan lainnya menyesuaikan keadaan lahan di lapangan. Masing-masing bedengan berukuran 100 $\mathrm{x} 100 \mathrm{~cm}$ dengan tinggi $15-20 \mathrm{~cm}$ karena keterbatasan lahan. Bedengan dibuat membujur dari Timur-Barat agar mendapat pencahayaan maksimal dari matahari.

\section{e. Penyemaian}

Tahap penyemaian untuk membuat kebun bibit dilakukan dengan menggunakan tray semai yang diisi media tanam kompos kemudian ditanami benih. Bibit yang telah tumbuh dipindahkan ke lahan bedengan dan vertikultur. Pada metode aquaponik dan hidroponik tidak dilakukan penyemaian tetapi benih langsung diletakan pada media tanam hidroponik yang telah berisi air nutrisi dan aquaponik yang telah berisi air dan bibit lele.

\section{f. Penanaman}

Setelah bibit memiliki 3-4 daun maka bibit siap dipindahkan ke lahan bedengan dan vertikultur.

\section{g. Pemeliharaan}

Pemeliharaan dilakukan secara rutin meliputi penyiraman pagi dan sore hari kecuali hujan, pemupukan satu minggu sekali, pengendalian hama secara mekanik, dan pemberian pakan lele secara rutin. Pada tahap pemeliharaan ini dilakukan pembuatan pupuk organik dengan memanfaatkan limbah dapur dan kotoran ternak dari masyarakat sekitar.

\section{h. Panen}

Pemanenan tanaman sayur dilakukan saat tanaman berumur 4-5 minggu setelah tanam. Hasil panen kemudiaan dikemas dan dibagikan ke masyarakat sekitar.

\section{Hasil dan Pembahasan}

\section{Kebun Bibit}

Kebun bibit menjadi salah satu sumber bibit dalam pengembangan kawasan Rumah Pangan Lestari sebagai upaya menuju terciptanya rumah pangan lestari (RPL). Kebun bibit bertujuan untuk menjadi tempat penyediaan bibit yang dapat dengan mudah diakses oleh masyarakat. Kebun bibit juga menjamin kesinambungan RPL dan menghasilkan keuntungan ekonomi melalui usaha penjualan bibit tanaman.

Kebun bibit dapat berupa lahan pembibitan yang dilengkapi dengan peralatan dan dikelola atas partisipasi aktif masyarakat untuk memproduksi bibit agar dapat memenuhi kebutuhan bibit tanaman warga masyarakat. Lahan untuk kebun bibit sebaiknya merupakan lahan terbuka agar mendapat 
banyak cahaya matahari langsung, serta berdekatan dengan sumber air (Werdhany, 2012).

Jenis sayuran yang disemai pada tray semai meliputi tanaman bayam hijau, bayam merah, sawi, selada, pakcoy, dan kangkung. Media semai terdiri dari pupuk organik dan tanah topsoil dengan perbandingan 1:1. Benih yang baru ditanam diletakkan pada tempat kering yang terhindar dari sinar matahari langsung dan hujan.

Pemeliharaan meliputi penyiraman setiap pagi dan sore menggunakan spray dan pemberian pupuk organik cair (mol). Benih yang sudah berkecambah dan muncul dua daun, diperkenalkan dengan sinar matahari pagi, umumnya benih sudah berumur satu minggu. Bibit yang telah berumur \pm 21 hari atau telah berdaun 3-4 helai, siap untuk dipindahkan ke polibag atau bedengan dengan jarak tanam $\pm 10 \mathrm{~cm}$.

Salah satu kegiatan dari program kerja kebun bibit adalah demonstrasi dan praktek yang melibatkan anak-anak di Lingkungan Karang Kateng Kelurahan Punia pada tanggal 5 Februari 2021 menggunakan bibit pakcoy dan bayam hijau. Kegiatan ini diawali dengan persemaian yang telah dilakukan 21 hari sebelumnya. Kemudian dilakukan pengenalan bibit dan media tanam, yang dilanjutkan dengan pemindahan bibit ke media polibag. Setiap anak menanam 4-8 bibit. Kegiatan ini berjalan dengan baik dan memperoleh apresiasi dari masyarakat.

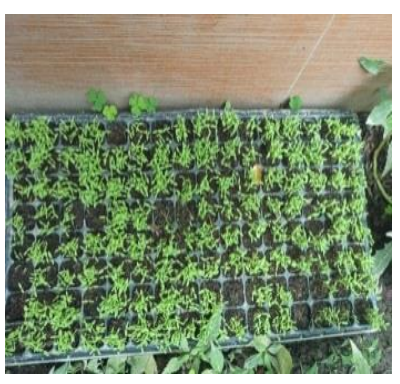

Gambar 1a. Pelaksanaan program kerja kebun bibit

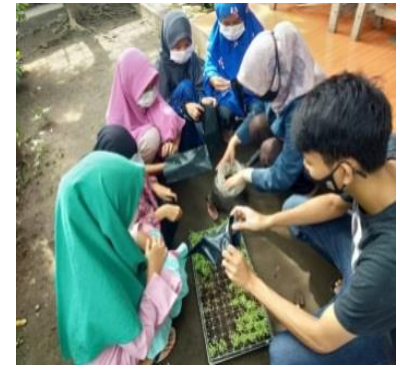

Gambar 1b. Kegiatan demonstrasi dan praktek

\section{Bedengan}

Bedengan berfungsi sebagai media tumbuh berbagai jenis tanaman budidaya pada lahan yang luas. Pertama-tama, dipastikan terlebih dahulu kondisi tanah untuk mengetahui kesuburan tanah dan menentukan jumlah pupuk yang dibutuhkan untuk media tanam. Tanah yang banyak mengandung pasir terasa kasar di jari-jari, tanah yang banyak debu terasa halus dijari, tetapi tidak lengket, sedangkan tanah yang banyak mengandung liat, terasa halus serta lengket (Wahyono, 2013).

Jumlah tanaman dalam bedengan sangat dipengaruhi oleh jarak tanam. Pada umumnya jarak tanam yang sering digunakan adalah $30 \mathrm{~cm} \times 70 \mathrm{~cm}$ dengan lebar bedengan $100 \mathrm{~cm}$. Penggunaan jarak tanam bertujuan untuk memberikan ruang sekitar pertumbuhan tanaman yang baik tanpa mengalami persaingan unsur hara dalam tanah antara tanaman satu dengan tanaman yang lainnya (Fatchullah, 2016).

Bibit yang ditanam di media bedengan yaitu sawi, bayam dan kangkung. Pemeliharaan dilakukan dengan penyiraman setiap pagi dan sore hari, penyiangan rumput dan gulma lain dengan mencabut gulma, pengendalian hama secara mekanik, serta pemberian pupuk daun GrowQuick dan urea agar tanaman tumbuh subur.

Kangkung dipanen pada umur 30 hari setelah penanaman dengan cara dicabut. Tanaman sawi dan bayam hijau dipanen saat tanaman berumur 43 hari dengan dicabut. Hasil panen dicuci dan dikemas dengan daun, kemudian dibagikan ke warga Lingkungan Punia Karang Kateng dan Punia Jamak.

\section{Vertikultur}

Vertikultur merupakan salah satu teknik bercocok tanam diruang sempit dengan memanfaatkan bidang vertikal sebagai tempat bercocok tanam yang dilakukan secara bertingkat. Metode vertikultur bertujuan untuk memanfaatkan lahan yang sempit secara optimal dan memanfaatkan kembali sampah plastik. Sampah plastik dimanfaatkan sebagai media vertikultur karena plastik menjadi salah satu jenis limbah yang mengancam kerusakan bumi. Plastik terbuat dari bahan sintetis sehigga sangat sulit untuk terdegradasi. Memanfaatkan kembali sampah plastik dapat menjadi solusi untuk dapat mengurangi penumpukan sampah plastik (Santosa, 2018).

Bibit bayam hijau, bayam merah, pakcoy dan selada ditanam pada media vertikultur. Pada kegiatan ini digunakan 21 botol plastik berisi tanaman. Botol-botol plastik tersebut disusun secara vertikal 3 tingkat. Pemeliharaan tanaman pada media vertikultur dilakukan dengan 
penyiraman air setiap pagi, pemberian pupuk daun GrowQuick dan urea, serta meletakkan media vertikultur di tempat yang terkena cahaya matahari langsung.

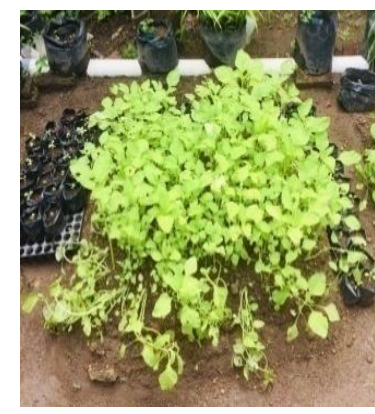

Gambar 2a. Penanaman dengan metode bedengan

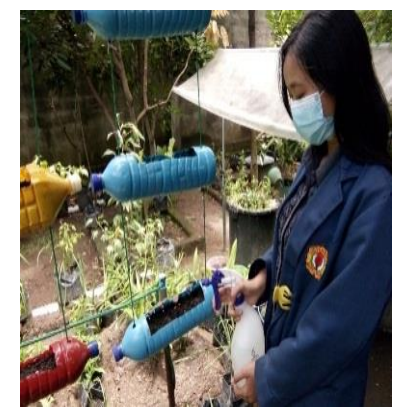

Gambar 2b. Penanaman dengan metode vertikultur
Pada kegiatan ini, paparan cahaya matahari langsung sangat berpengaruh pada pertumbuhan tanaman. Pada minggu ke-3 hingga ke-4, media vertikultur diletakkan di tempat yang tidak banyak terpapar sinar matahari, sehingga tanaman tidak dapat tumbuh dengan baik. Pada minggu ke-5 dilakukan penanaman kembali dan pemindahan media vertikultur ke tempat yang terpapar cahaya matahari langsung. Pengamatan menunjukkan tanaman tumbuh dengan subur. Hal ini dikarenakan cahaya matahari merupakan faktor penting terhadap berlangsungnya fotosintesis.

\section{Aquaponik}

Aquaponik merupakan perpaduan antara akuakultur (budidaya ikan) dengan hidroponik (budidaya tanaman tanpa tanah, tetapi memanfaatkan air bernutrisi) dengan menggunakan kolam plastik. Aquaponik memiliki kemampuan untuk memproduksi protein, sehingga pemanfaatan aquaponik dapat memanen sayuran dan ikan dari satu wadah dalam waktu yang bersamaan. Saat ini budidaya tanaman dengan sistem aquaponik adalah alternantif yang tepat untuk mendapatkan sayuran dan buah-buahan (Hasanah, 2020) dan protein (ikan) di lahan yang sempit atau terbatas .

Adapun untuk tanaman yang ditanam pada sistem aquponik ini adalah kangkung, pakcoy, sawi dan selada. Media tanam yang digunakan adalah arang kayu, namun arang kayu memiliki tingkat kepadatan yang tidak solid sehingga digunakan tissu sebagai alas agar benih sayur tidak jatuh ke air. Arang kayu dalam metode aquaponik juga berfungsi sebagai filter bagi air untuk menurunkan konsentrasi ammonia (Diansari, 2013). Benih yang ditabur membutuhkan waktu 3-5 hari untuk mulai berkecambah.

Selada dan kangkung menunjukan tingkat pertumbuhan yang baik. Kangkung tumbuh hingga mencapai ketinggian $\pm 10 \mathrm{~cm}$, sedangkan sawi dan pakcoy tidak bisa tumbuh dengan baik Hal ini dikarenakan benih yang disemai terlalu banyak sehingga terjadi persaingan dalam memperebutkan unsur hara.

Ikan yang dibudidaya adalah ikan lele. Ikan lele diandalkan dalam penyediaan makanan organik dan nutrisi untuk membantu tanaman tumbuh. Tanaman membersihkan, menyaring dan mendaur ulang air kembali ke ikan sehingga akan tercipta hubungan simbiosis (Hasanah, 2020). Ukuran bibit lele yang digunakan adalah $4 \mathrm{~cm}$. Namun, bibitbibit lele tersebut diduga setres saat dipindahkan ke tempat baru, sehingga hanya bertahan hidup selama 4 hari saja. Pada minggu ke-3, aquaponik diisi kembali dengan 10 ekor lele yang berukuran lebih besar pada air yang sudah didiamkan selama satu minggu. Beberapa lele mati tetapi sisanya masih bertahan hingga akhir kegiatan.

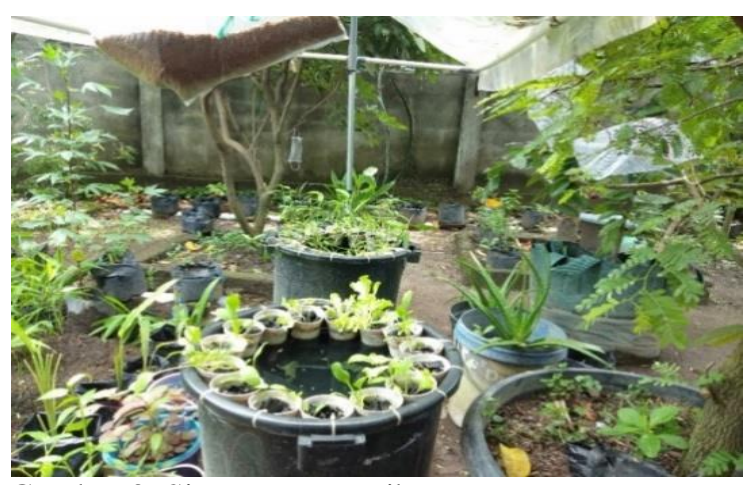

Gambar 3. Sistem aquaponik

\section{Hidroponik}

Hidroponik adalah budidaya pertanian tanpa menggunakan media tanah, sehingga hidroponik merupakan aktivitas pertanian yang dijalankan dengan menggunakan air sebagai medium untuk menggantikan tanah. Hal ini menyebabkan budidaya tanaman secara hidroponik dapat memanfaatkan lahan yang sempit (Murtadha, 2016).

Sistem hidroponik yang diterapkan pada program kerja ini yaitu hidroponik sistem wick. 
Sistem ini sangat mudah diterapkan bagi pemula yang ingin bercocok tanam sayur di rumah. Teknologi ini tidak memerlukan listrik dan mudah dalam merancang alatnya.

Kegiatan ini menerapkan dua media hidroponik. Pertama, menggunakan ember dan keranjang nasi yang diletakan diatas ember, kemudian kain flannel sebagai sumbu dan media tanamnya. Benih yang ditanam yaitu bayam merah, bayam hijau, sawi, dan kangkung. Nutrisi AB Mix diberikan sebesar 1300 ppm sejak mulai benih ditabur (semai).

Pada hari kedua, benih mulai berkecambah. Persentase tanaman yang tumbuh yaitu $93 \%$. Pada umur dua minggu setelah tanam, beberapa tanaman layu dan terlihat seperti terbakar dan membusuk. Tanaman yang membusuk diantaranya satu ember bayam merah dan dua ember sawi. Kemudian tanaman yang mati diganti dengan menyemai ulang. Menurut Wasonawati, (2011), pada konsentrasi $\mathrm{AB}$ Mix yang terlalu rendah pengaruh larutan hara tidak nyata, sedangkan pada konsentrasi yang terlalu tinggi selain boros juga akan mengakibatkan tanaman mengalami plasmolisis, yaitu keluarnya cairan sel karena tertarik oleh larutan hara yang lebih pekat.

Penanaman kembali dilakukan untuk mengganti tanaman yang mati dengan penyemaian menggunakan media air saja. Setelah 21 hari setelah semai (HSS) pertumbuhan tanaman terlihat sangat lambat. Tanaman bayam merah, bayam hijau dan sawi hanya mengeluarkan 2-4 daun. Pada saat itu konsentrasi air nutrisi yang digunakan 1300 PPM, sama seperti saat pertamakali semai. Hal ini diduga akibat pemeberian nutrisi yang tidak sesuai. Dugaan ini didukung oleh Hidayanti dan Kartika (2019) yang menjelaskan bahwa pemberian unsur hara dapat meningkatkan pertumbuhan tanaman dalam jumlah yang sesuai kebutuhan tanaman. Jika terlalu berlebihan dapat menghambat pertumbuhan dan perkembangan tanaman. Sebagai solusi, konsentrasi air nutrisi diturunkan menjadi 10001100 ppm. Hasilnya tanaman sawi, bayam hijau, dan bayam merah dapat tumbuh lebih baik.

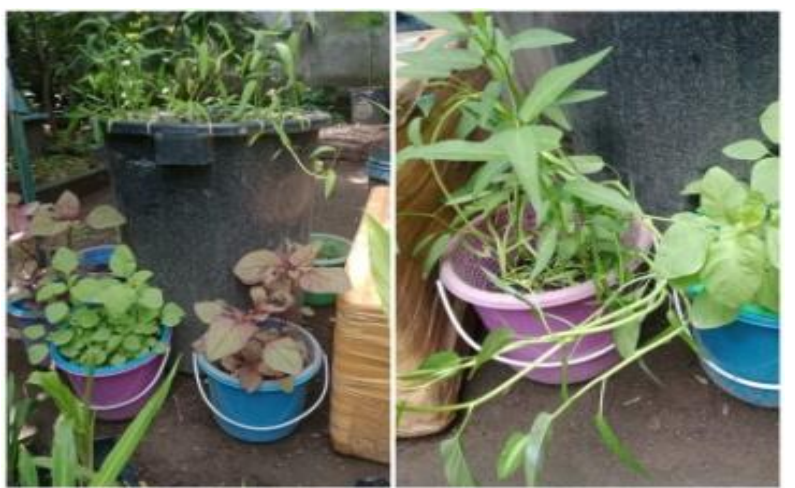

Gambar 4a. Hidroponik dengan keranjang (38 hss)

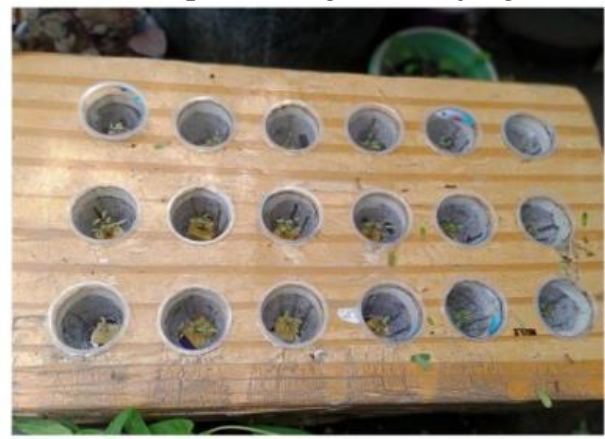

Gambar 4b. Hidroponik dengan box styrofoam (15 hss)

Pembuatan media hidproponik yang kedua yaitu menggunakan box styrofoam bekas. Tanaman yang ditanam yaitu bayam merah. Penyemaian dilakukan hanya menggunakan media air. Hasilnya tidak ada tanaman yang mati seperti kasus pada pembuatan hidroponik pertama dengan ember. Saat ini tanaman baru berusia 15 HSS sehingga belum dapat dipanen. Pada usia ini tanaman mulai diberikan nutrisi $\mathrm{AB}$ Mix sebesar 300 ppm.

Perawatan pada tanaman hidroponik yaitu rutin memeriksa kondisi air nutrisi baik itu konsentrasi nutrisi maupun kebersihan media. Tanaman diletakan di tempat yang terkena cukup cahaya matahari. Beberapa hama yang menyerang diantaranya belalang dan ulat. Hama tersebut dikendalikan secara mekanik (menangkap dan membunuh hama). Pemberian pupuk daun GrowQuick dilakukan untuk merangsang pertumbuhan vegetatif tanaman. 
Pembuatan Mikroorganisme Lokal (mol) dan Kompos

Bahan organik merupakan bahan esensial yang berperan mempertahankan dan memperbaiki tekstur dan struktur tanah. Selain itu, bahan organik sebagai sumber nutrisi bagi beberapa mahluk hidup di dalam tanah termasuk tumbuhan. Upaya dalam penyediaan bahan organik tersebut dapat dilakukan dengan pengembangan Mikro Organisme Lokal (MOL) dan pembuatan kompos dari limbah organik rumah tangga. Limbah organik rumah tangga seperti sisa sayuran dan air cucian beras masih dapat dimanfaatkan untuk membuat pupuk organik yang memiliki kemanfaatan lebih baik (Sasongko, 2019)

Bahan utama mol terdiri dari beberapa komponen yaitu karbohidrat, glukosa, dan sumber mikroorganisme. Bahan dasar untuk fermentasi larutan mol dapat berasal limbah organik rumah tangga. Karbohidrat merupakan sumber nutrisi untuk mikroorganisme dalam pupuk organik cair (POC). Sumber karbohidrat berasal dari limbah organik, seperti air cucian beras dan pisang matang. Sumber glukosa berasal dari gula pasir. Keberhasilan mol terlihat dari sudah tidak adanya gas, dengan cara mengeluarkan gas setiap hari. Selain itu, tanda-tanda keberhasilan mol juga adalah beraroma khas tape sebagai hasil fermentasi (Sasongko, 2019).

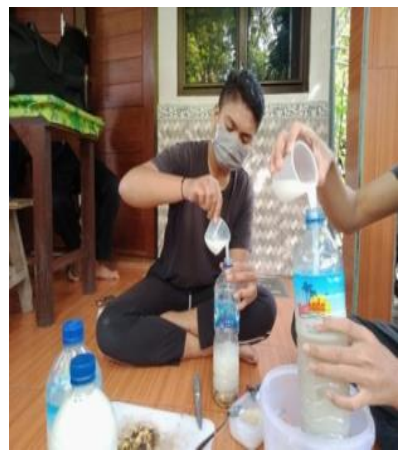

Gambar 5a. Pembuatan mol

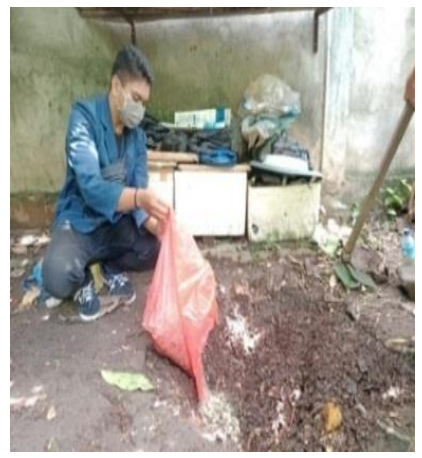

Gambar 5b. Pembuatan pupuk kompos
Pengomposan merupakan suatu teknik pengolahan limbah padat yang mengandung bahan organik biodegradable (dapat diuraikan mikroorganisme). Selain menjadi pupuk organik, kompos juga dapat memperbaiki struktur tanah, memperbesar kemampuan tanah dalam menyerap air dan menahan air serta zat-zat hara lain. Pengkomposan alami akan memakan waktu yang relatif lama, yaitu sekitar 2-3 bulan bahkan 6-12 bulan (Subandriyo, 2012).

Sampah organik yang diperoleh dicampur dengan tanah, kotoran ayam sebagai sumber nitrogen, dan penambahan mol yang sudah diencerkan. Subandriyo (2012) menjelaskan pengomposan dapat berlangsung dengan fermentasi yang lebih cepat dengan bantuan mikroorganisme. Pupuk kompos yang belum jadi disimpan di dalam ember sebagai wadah penyimpanan kompos. Kompos disimpan dalam keadaan yang lembab dan tidak terkena sinar matahari langsung. Hingga kegiatan KKN berakhir, kompos yang dibuat belum jadi. Keberlanjutan RPL diserahkan kepada masyarakat di sekitar Lingkungan Karang Kateng.

\section{Kesimpulan}

Berdasarkan uraian pelaksanaan program kerja KKN Tematik Rumah Pangan Lestari Universitas Mataram yang bertempat di Lingkungan Punia Karang Kateng, Kelurahan Punia, Kecamatan Mataram, Kota Mataram dapat disimpulkan kegiatan ini berjalan dengan sangat baik, dengan antusias masyarakat yang tinggi serta dukungan dari pemerintah setempat yang sudah mewadahi.

\section{Ucapan Terima Kasih}

Ucapan terima kasih disampaikan kepada Universitas Mataram khususnya Lembaga Penelitian dan Pengabdian Kepada Masyarakat UNRAM, Lurah Punia dan masyarakat Lingkungan Karang Kateng Kelurahan Punia.

\section{Daftar Pustaka}

Diansari, R. V. R., Arini, E., dan Elfitasari, T. 2013. Pengaruh kepadatan yang berbeda terhadap kelulushidupan dan pertumbuhan ikan nila (Oreochromis niloticus) pada sistem resirkulasi dengan filter zeolit. Journal of Aquaculture Management and Technology. 1(1): 37-45.

Fatchullah, D. 2016. Pengaruh Lebar Bedengan dan Jarak Tanam Terhadap Pertumbuhan dan Hasil Benih Kentang (Solanum tuberosum L.) Generasi Dua (G2) Varietas Granola. Prosiding Seminar Nasional Pengembangan Teknologi Pertanian. 1(1): 
39-47.

Hasanah, Z., Tony Y., dan Ira Y. 2020. Pendampingan Optimalisasi Pemanfaatan Lahan Pekarangan Rumah Sebagai Tempat Tanaman Baru Aquaponik. SENIAS. 1(1): 26-29.

Hidayanti, L., dan Kartika T. 2019. Pengaruh Nutrisi AB Mix Terhadap Pertumbuhan Tanaman Bayam Merah (Amaranthus tricolor L.) Secara Hidroponik. Jurnal Ilmiah Matematika dan Ilmu Pengetahuan Alam. 16(2): 1-10.

Khairati, R., dan Rahmat S. 2016. Respons Permintaan Pangan Terhadap Pertambahan Penduduk di Sumatera Barat. Jurnal Pembangunan Nagari. 1(2): 19-36.

Murtadha, R. R., Anita W. N. T., Deva M., Nur L. A., Suci R. F., dan Laila L. U. 2016. Optimalisasi Lahan Dengan Memanfaatkan Sistem Hidroponik.

Sasongko, H., dan Zuchrotus S. 2019. Optimalisasi lahan pekarangan rumah dengan budidaya tanaman sayuran organik di Dusun Krajan Desa Somongari Kec. Kaligesing Kab. Purworejo. Seminar Nasional Hasil Pengabdian kepada Masyarakat UAD. 1(1): 1-8.

Satiti, S. 2019. Gerakan Ayo Sekolah Di Kabupaten Bojonegoro: Peningkatan Sumber Daya Manusia Melalui Pendidikan Untuk Menyongsong Bonus Demografi. Jurnal Kependudukan Indonesia. 14(1): 77-92.

Sholehah, N., Mimien H. I., dan Sueb. 2016. Kawasan Rumah Pangan Lestari (KRPL): Analisis Pengetahuan dan Perilaku Santri. Jurnal Pendidikan Sains. 4(4): 152-156.

Sikumalay, A., Neni S., dan Machdawaty M. 2016. Efek Antibakteri dari Rebusan Daun Sambiloto (Andrographis paniculata Nees) dan Produk Herbal Sambiloto Terhadap Staphylococcus aureus. Jurnal Kesehatan Andalas. 5(1): 196-200.

Subandriyo., Didi D. A., dan Hadiyanto. 2012. Optimasi Pengomposan Sampah Organik Rumah Tangga Menggunakan Kombinasi Aktivator Em4 Dan Mol Terhadap Rasio C/N. Jurnal Ilmu Lingkungan. 10(2): 7075.

Suryani, Reni N., dan Rini F. 2020. Pemanfaatan Lahan Sempit Perkotaan untuk Kemandirian Pangan Keluarga. Jurnal
Ilmiah Respati 11(2): 93-103.

Wahyono, E. H., Haerudin R. S., Bambang R. S., Nano S., Jueni., Edi H., Bambang L., Ayu A. J., Bonaji., Erwindo., Suhadi., dan Sutarto. 2013. Pertanian Alami. Bogor: Konsorsium YABI-WCS-YAPEKA.

Wasonawati, C. 2011. Meningkatkan Pertumbuhan Tanaman Tomat (Lycopersicon esculentum) dengan Sistem Budidaya Hidroponik. Jurnal Agrovigor. 4(1): 1-11.

Werdhany, W. I., dan Gunawan. 2012. Teknik Pengembangan Kawasan Rumah Pangan Lestari Di Daerah Istimewa Yogyakarta. Jurnal Ilmu-ilmu Pertanian. 16(2): 76-83. 